\title{
Prevalence and Risk Factors for Lumpy Skin Disease in Cattle and Buffalo under Subtropical Environmental Conditions
}

\section{Dina Nasser Faris ${ }^{*}$, Khairy El-Bayoumi ${ }^{2}$, Mahmoud El-Tarabany ${ }^{2}$, Eman Ramadan Kamel ${ }^{1}$}

${ }^{1}$ Department of Animal Wealth Development, Faculty of Veterinary Medicine, Benha University,P.O. Box 13736 El-Qalyubia, Egypt; ${ }^{2}$ Department of Animal Wealth Development, Faculty of Veterinary Medicine, Zagazig University,P.O. Box 44511 Sharkia, Egypt.

\begin{abstract}
Lumpy skin disease (LSD) is an infectious viral disease with major economic impacts on the animal wealth in different countries and it became endemic in Egypt. The present study was carried out to investigate the prevalence of LSD in El-Qalyubia governorate, Egypt, and the related risk factors. In total, 665 blood samples were collected from diseased and apparently healthy animals to detect positive cases. The prevalence of LSD was higher in cattle (36.7\%) than in buffalo (15.2\%). The animals of age 1-2 years and over 2 years showed a higher prevalence of LSD (42.2\% and $34.9 \%$, respectively) than young animals of age less than one year $(26.3 \%)$. The prevalence was higher in summer and spring (37.7\% and 34.1\%, respectively) than in the winter season. Also, the highest prevalence of LSD was reported at a high THI level $>80(37.6 \%)$. Regarding the locality, Benha, Qaha, and E1-Khanater El-Khayria showed the highest prevalence of LSD (45.6\%, 44.4\%, and 38.4\% respectively). Also, the prevalence of LSD in non-vaccinated animals (50\%) was higher than in vaccinated animals (34.3\%). A univariate logistic regression model was applied to evaluate the risk factors of LSD, followed by forward stepwise multivariate logistic regression. The final multivariate model revealed that the seroprevalence of LSD was significantly associated with animal species and age. Cattle and animals of age 1-2 years have a higher likelihood to be infected with the LSD compared with their contemporaries $(\mathrm{OR}=4.08$ and $2.35 ; \mathrm{P}=$ $>0.001$ and $<0.001$, respectively). Therefore, early detection of LSD seropositivity among cattle of age $1-2$ years and the application of control measures among localities are the methods of choice to minimize future LSD outbreaks in Egypt.
\end{abstract}

Keywords | Lumpy Skin disease, Odds ratio, Logistic regression, Prevalence, Risk Factors

Received | March 05, 2021; Accepted | April 28, 2021; Published | July 28, 2021

${ }^{*}$ Correspondence | Dina Nasser Faris, Department of Animal Wealth Development, Faculty of Veterinary Medicine, Benha University,P.O. Box 13736 El-Qalyubia, Egypt; Email: dina.abdallah@fvtm.bu.edu.eg

Citation | Faris DN, El-Bayoumi K, El-Tarabany M, Kamel ER (2021). Prevalence and risk factors for lumpy skin disease in cattle and buffalo under subtropical environmental conditions. Adv. Anim. Vet. Sci. 9(9): 1311-1316.

DOI | http://dx.doi.org/10.17582/journal.aavs/2021/9.9.1311.1316

ISSN (Online) | 2307-8316; ISSN (Print) | 2309-3331

Copyright (c) 2021 Faris et al. This is an open access article distributed under the Creative Commons Attribution License, which permits unrestricted use, distribution, and reproduction in any medium, provided the original work is properly cited.

\section{INTRODUCTION}

$\mathrm{L}$ umpy skin disease (LSD) is a viral infectious disease caused by a virus (LSDV) in the family Poxviridae, genus Capripoxvirus which is closely related antigenically to poxvirus of sheep and goat. LSD is also referred to as Neethling virus disease, Pseudo-urticaria, and Exanthema Nodularis Bovis. The main species affected by LSD are cattle, though the infection has also been reported in water buffalo (Al-Salihi, 2014; Kiplagat et al., 2020). LSD is characterized by skin nodules with enlarged inflamed lymph nodes accompanied by a high persistent fever, pneumonia, lacrimation, and nasal discharge (Al-Salihi and
Hassan, 2015). The morbidity rate of LSD ranges from 3 to $85 \%$ in different epizootic situations while in the endemic areas, the morbidity rate is estimated at $10 \%$ and mortality rate of LSD varies between 1 and 3\%, but percentage up to $40 \%$ have been reported in severe outbreak conditions (Ochwo et al., 2019).

The World Organization for Animal Health (OIE) classifies LSD as a notifiable disease due to the considerable economic impact of an LSD outbreak that comes from:

1. The disease is more serious in cows especially through the peak of lactation result in a sharp decline in milk 
yield because of the persistent high fever that results on the viral infection itself and secondary bacterial mastitis.

2. In cows and bulls may occur temporary or permanent infertility.

3. Infected animals suffer from emaciation and decreased growth rate in beef cattle may occur as a result of the long convalescence period that takes several months.

4. Deep skin lesions leave permanent scars and decrease the quality of hides.

5. Significant financial losses on a national level result from restrictions on the worldwide trade of live animals and animal products, expensive control strategies, and eradication measures such as vaccination campaigns (Weiss, 1968; Tuppurainen and Oura, 2012).

Historically, the first outbreak of LSD in Egypt was in 1988 in the Suez government after the importation of cattle from Africa, and then the disease reappeared in the summer of 1989 and continue for five to six months with a low morbidity rate due to the vaccination procedure with the sheep pox vaccine. In the summer of 2006, the LSD outbreak was re-emerged once again in several Egyptian governorates, where all age groups and both sex of Egyptian cattle were infected with severe and serious complications (Ahmed and Dessouki, 2013; Al-Salihi, 2014). The occurrence of LSD was also confirmed in Egypt in 2011 and 2014 and there was an outbreak of the disease in Egypt in 2018 (Allam et al., 2020).

Diagnosis of LSDV can be performed by observation of the characteristic clinical signs, virus isolation, electron microscopy, histopathological examination, serological, and molecular techniques (Abdallah et al, 2018). Hence, the aim of this study is firstly to assess the prevalence of LSD in five selected localities in El-Qalyubia governorate, Egypt. Secondly, to detect the potential risk factors associated with LSD, such as animal species, age, season, temperature-humidity index (THI), locality, and immune status of the examined animals.

\section{MATERIALS AND METHOD}

\section{Study Design}

A cross-sectional seroprevalence study was carried out within the period extended from March 2018 to November 2018 to assess the prevalence of LSD in five selected localities (El-khanka, Benha, Qalyub, El-Kanater El-Khayria, and Qaha) in El-Qalyubia governorate, Egypt, and evaluate the potential risk factors associated with LSD.

Data Collection and the Explanatory Variables In total, 665 blood samples were collected from cattle $(\mathrm{n}=599)$ and buffalo $(\mathrm{n}=66)$. Samples were collected from diseased animals showing the clinical signs of LSD and their apparently healthy contemporaries. The majority of examined animals had a history of vaccination with the sheep pox vaccine (97.9\%).

Temperature-humidity index (THI) is a single value representing the combined effects of air temperature and humidity associated with the level of thermal stress. According to the date of sample collection, daily records of relative humidity and ambient temperature were collected from the nearest meteorological station. The raw data were used to calculate the daily THI in accordance with a previously reported equation (Kendall and Webster, 2009). THI $=(1.8$ $\times \mathrm{AT}+32)-[(0.55-0.0055 \times \mathrm{RH}) \times(1.8 \times \mathrm{AT}-26)]$, where $\mathrm{AT}=$ Air temperature $\left({ }^{\circ} \mathrm{C}\right), \mathrm{RH}=$ Relative humidity (\%).

The possible explanatory variables included in this study were animal species (cattle and buffalo), age (3 levels: < 1year; 1-2 years and > 2 years), season (winter, spring, and summer), temperature-humidity index (THI: low < 70; moderate 70-80, and high $>80$ ), locality (El-Khanka, Benha, Qalyub, El-Kanater E1-Khayria, and Qaha), and immune status of examined animals (Vaccinated and Non-vaccinated).

\section{Data Management and Statistical Analysis}

All Statistical analysis procedures were conducted by the SPSS statistical software package (SPSS version 25). In order to analyze the collected data, the apparent animal-level of LSD seroprevalence was obtained by dividing the number of the infected animals by the number of total examined animals. Then to assess the impact of the possible risk factors (animal species, age, season, THI, locality immune status) on the seropositivity of the LSD, univariate and multivariate logistic regression models were performed. All results are considered significant at the level of significance $0.05(\mathrm{p}<0.05)$.

Firstly, a univariate logistic regression model was conducted using only one explanatory variable to assess its relationship with the outcome variable (LSD seropositivity) using the likelihood ratio test, depending on the following equation:

$$
\log \left(\frac{P}{1-P}\right)=\alpha+\beta_{1} X_{1}
$$

Where;

$(\mathrm{P} / 1-\mathrm{P})$ is the odds, $P$ is the probability of LSD seropositivity, $\alpha$ is the $Y$-intercept of the model, $\beta_{1}$ is the regression coefficient, and $X_{1}$ is the explanatory variable entered the model. The results were expressed as the odds ratio (OR) of the associated risk factor at confidence interval (CI) 95\% and $P$-value. 
Before conducting the multivariate analysis, the absence of multicollinearity between the explanatory variables was checked using tolerance and variance inflation factor (VIF). Multicollinearity is considered if tolerance $<0.04$ and VIF > 10 (Dohoo et al., 2003). If variables were collinear one of them was removed and then the remaining variables enter the multivariate logistic regression with forward elimination procedure. The overall goodness of fit of the final selected model was tested using the receiver operating characteristic curve (ROC curve) and area under the curve (AUC). The model is considered fit if AUC is more than 0.5 and the $p$-value is less than 0.05 .

Using the procedure of forward stepwise variable selection, multivariate logistic regression was conducted to determine the best-fitted model. Forward stepwise variable selection depends on starting with an empty model, testing the addition of each explanatory variable using the chosen model fit criterion (maximum likelihood ratio test), adding the variable whose inclusion provides the best statistically significant improvement of the fit, and repeating this process until none improves the model to a statistically significant extent. The equation of the multivariate logistic regression is:

$$
\log \left(\frac{P}{1-P}\right)=\alpha+\beta_{1} X_{1}+\cdots+\beta_{k} X_{k}
$$

The results were expressed as the coefficient of regression $(\beta)$, the standard error (SE) of the coefficient, Wald value, and the odds ratio (OR) of the associated risk factor at confidence interval (CI) $95 \%$ and $P$-value.

\section{RESULTS AND DISCUSSION}

The 2018 LSD outbreak in Egypt appeared with a vigorous clinical picture with a high morbidity rate and considerable economic losses of meat and milk. Male cattle showed sterility, and infertility was observed in the females (Allam et al., 2020). LSD is currently endemic in most African countries and has spread from Africa to the Middle East region, including Egypt, and it still circulates in cattle in Egypt and its recurrence indicates that epidemics are likely despite the use of routine vaccination programs (Hodhod et al., 2020).

Data summarizing the factors associated with LSD seropositivity are illustrated in Table 1 . The first part of the study was on the seroprevalence of LSDV in El-Qalyubia governorate during the period extended from March to November 2018. The overall prevalence of LSD among the studied population (665 animals) was $34.6 \%$. The current study reported that the prevalence of LSD was higher in cattle (36.7\%) than in buffalo (15.2\%) which was in agree- ment with Tuppurainen and Oura (2012), who reported that the morbidity rate in buffalo was significantly lower than in cattle during the 1988 LSD outbreak in Egypt (1.6\% and $30.8 \%$ respectively). Under natural exposure conditions, Elhaig et al. (2014) also reported that LSD infection in buffalo is a controversial problem and during the outbreaks, buffalo are apparently healthy and did not show any lesions.

Table 1: Factors Associated with Lumpy Skin Disease Seropositivity in Cattle and Buffalo.

\begin{tabular}{|c|c|c|c|c|}
\hline $\begin{array}{l}\text { Fac- } \\
\text { tors }\end{array}$ & Class & $\begin{array}{l}\text { No. of } \\
\text { total } \\
\text { examined } \\
\text { animals }\end{array}$ & $\begin{array}{l}\text { No. of infected } \\
\text { animals }\end{array}$ & $\begin{array}{l}\text { Prevalence of } \\
\text { infection (\%) }\end{array}$ \\
\hline \multirow{3}{*}{$\begin{array}{l}\text { Overall } \\
\text { Animal } \\
\text { Species }\end{array}$} & & 665 & 230 & $34.6 \%$ \\
\hline & Cattle & 599 & 220 & $36.7 \%$ \\
\hline & Buffalo & 66 & 10 & $15.2 \%$ \\
\hline \multicolumn{5}{|l|}{ Age } \\
\hline & $<1$ year & 179 & 47 & $26.3 \%$ \\
\hline & $1-2$ years & 180 & 76 & $42.2 \%$ \\
\hline & $>2$ years & 306 & 107 & $34.9 \%$ \\
\hline \multicolumn{5}{|c|}{ Season } \\
\hline & Winter & 225 & 66 & $29.3 \%$ \\
\hline & Spring & 47 & 16 & $34.1 \%$ \\
\hline & Summer & 393 & 148 & $37.7 \%$ \\
\hline \multicolumn{5}{|l|}{ THI } \\
\hline & Low $(<70)$ & 236 & 70 & $29.7 \%$ \\
\hline & $\begin{array}{l}\text { Moderate } \\
(70-80)\end{array}$ & 19 & 6 & $31.6 \%$ \\
\hline & $\operatorname{High}(>80)$ & 410 & 154 & $37.6 \%$ \\
\hline \multicolumn{5}{|c|}{ Locality } \\
\hline & El-Khanka & 235 & 69 & $29.4 \%$ \\
\hline & Benha & 57 & 26 & $45.6 \%$ \\
\hline & Qalyub & 87 & 24 & $27.6 \%$ \\
\hline & $\begin{array}{l}\text { El-Kanater } \\
\text { El-Khayria }\end{array}$ & 268 & 103 & $38.4 \%$ \\
\hline & Qaha & 18 & 8 & $44.4 \%$ \\
\hline \multicolumn{5}{|c|}{ Immunization } \\
\hline & $\begin{array}{l}\text { Not vacci- } \\
\text { nated }\end{array}$ & 14 & 7 & $50 \%$ \\
\hline & Vaccinated & 651 & 223 & $34.3 \%$ \\
\hline
\end{tabular}

Regarding the age factor, the incidence of LSD was higher in adult animals compared with young age. The animals of age 1-2 years and over 2 years showed a higher prevalence of LSD ( $42.2 \%$ and $34.9 \%$, respectively) than young animals of age less than one year (26.3\%) which might be attributed to the stress factors of pregnancy, lactation, and fattening. Consistent with our findings, Abd Elmohsen et 
al, (2019) found that the disease prevalence in older animals (12-50 month) was higher than in young animals (312 months) and also this might be due to the low frequency of exposure because calves are kept at home away from biting insects (Ochwo et al., 2019). On the contrary, Ayelet et al., (2014) reported that young ages are more susceptible to LSD infection. Concerning the effect of season, the incidence of LSD was the highest in the summer season (37.7\%), followed by the spring (34.1\%), and winter season (29.3\%). This might be due to the wet and warm weather conditions, with a subsequent increase in vector population density (Molla et al., 2018). These results were in agreement with Salib and Osman (2011) who reported that the LSD outbreaks were recorded during the summer season that this might be related to insect population which plays a very vital role in the disease transmission. Similarly, Abd Elmohsen et al. (2019) found that the highest prevalence of LSD was reported in the summer season. In accordance with the temperature-humidity index (THI), the prevalence of LSD was higher at high (37.6\%) and moderate (31.6\%) levels compared with the low THI level (29.7\%). This might be due to hot, humid, and wet weather conditions, which enhance the growth and spread of the natural hosting insects (Gari et al., 2015).

Also, the prevalence rate of LSD fluctuated among different localities. The reported prevalence was $45.6 \%, 44.4 \%$, $38.4 \%, 29.4 \%$, and $27.6 \%$ in Benha, Qaha, El-Kanater El-Khayria, El-Khanka, and Qalyub, respectively. The highest prevalence was observed in Benha, Qaha, and El-Khanater El-Khayria. This might be attributed to the existence of water bodies and the spread of cultivated areas, resulting in a rapid propagation of insect populations (Molla et al., 2018), or might be as a result of farmers' refusal to vaccinate their animals. Regarding the immune status, the incidence of LSD in non-vaccinated animals (50\%) was higher than that in vaccinated animals (34.3\%). Although lumpy skin disease virus and sheep pox virus are genetically and antigenically related (Bhanuprakash et al., 2006), immunized animals by sheep pox vaccine showed a relatively high prevalence rate of LSD. This might be attributed to the use of a low dose of sheep pox vaccine in large ruminants or mishandling of the vaccine during storage and transportation. This result agrees with Salib and Osman (2011) and Ince and Türk (2019).

In the current study, different risk factors were considered and examined by univariate logistic regression for the presence of any association with seropositivity of Lumpy skin disease infection. The univariate logistic regression analysis showed that animal species, age, and locality were significantly associated with the seropositivity of LSD (Table 2). None of the three variables showed multicollinearity, and thus all were included in the multivariate logistic regression model $(P<0.05)$.
Table 2: The Odds Ratio for Different Factors Affecting the Prevalence of LSD in Cattle and Buffalo using Univariate Logistic Regression Model.

\begin{tabular}{|c|c|c|c|c|}
\hline Factors & Class & OR & $95 \% \mathrm{CI}$ & P-value \\
\hline \multicolumn{5}{|c|}{ Animal Species } \\
\hline & Cattle & 3.25 & $1.6-6.5$ & 0.001 \\
\hline & Buffalo & Reference & - & \\
\hline \multicolumn{5}{|l|}{ Age } \\
\hline & $<1$ year & Reference & - & 0.006 \\
\hline & $1-2$ years & 2.05 & $1.32-3.2$ & \\
\hline & $>2$ years & 1.51 & $1.01-2.27$ & \\
\hline \multicolumn{5}{|l|}{ Season } \\
\hline & Winter & Reference & - & \\
\hline & Spring & 1.24 & $0.64-2.43$ & 0.11 \\
\hline & Summer & 1.46 & $1.02-2.07$ & \\
\hline \multicolumn{5}{|l|}{ THI } \\
\hline & Low $(<70)$ & Reference & - & \\
\hline & $\begin{array}{l}\text { Moderate } \\
(70-80)\end{array}$ & 1.09 & $0.4-2.9$ & 0.12 \\
\hline & High $(>80)$ & 1.43 & $1.01-2.01$ & \\
\hline \multicolumn{5}{|l|}{ Locality } \\
\hline & El-Khanka & Reference & - & \\
\hline & Benha & 2.02 & $1.12-3.65$ & \\
\hline & Qalyub & 0.92 & $0.53-1.59$ & 0.036 \\
\hline & $\begin{array}{l}\text { El-Kanater } \\
\text { El-Khayria }\end{array}$ & 1.5 & $1.03-2.18$ & \\
\hline & Qaha & 1.925 & $0.73-5.08$ & \\
\hline \multicolumn{5}{|c|}{ Immunization } \\
\hline & $\begin{array}{l}\text { Not vacci- } \\
\text { nated }\end{array}$ & Reference & & 0.224 \\
\hline & Vaccinated & 0.52 & $0.18-1.5$ & \\
\hline
\end{tabular}

$\mathrm{OR}=$ odds ratio, $\mathrm{CI}=$ confidence interval

As shown in Table 3, the forward stepwise multivariate logistic regression with likelihood ratio test was applied to optimize the best-fitted multiple logistic regression model. The final model showed that the seroprevalence of LSD was significantly associated with animal species and age. Cattle and animals of age 1-2 years have a higher likelihood to be infected with the LSD compared with their contemporaries $(\mathrm{OR}=4.08$ and $2.35 ; \mathrm{P}=<0.001$ and $<0.001$, respectively). This is similar to the results of Ochwo et al. (2019) who suggested that cattle above 25 months of age were found to have higher odds of infection than the young aged cattle. Abera et al. (2015) also recorded higher odds in adult $(\mathrm{OR}=3.41)$ and young $(\mathrm{OR}=1.86)$ cattle compared to calves.

The overall goodness of fit of the final selected model was illustrated in the ROC curve (Figure 1). The area under the curve was 0.61 at $95 \%$ confidence interval $(0.56-0.65)$. 
Also, the area under the curve is significantly different from $0.5(\mathrm{P}<0.001)$, confirming a significant validation of the final best fitted multivariate logistic regression model.

Table 3: Risk Factors from the Final Best Fitted Multiple Logistic Regression Model for LSD Prevalence in Cattle and Buffalo.

\begin{tabular}{|c|c|c|c|c|c|c|c|}
\hline \multicolumn{2}{|c|}{ Factors Class } & $\boldsymbol{\beta}$ & S.E. & Wald & OR & $95 \%$ CI & P-value \\
\hline \multicolumn{2}{|c|}{ Animal Species } & & & & & & $0.000^{\text {*** }}$ \\
\hline & Cattle & 1.406 & 0.37 & 14.4 & 4.08 & $1.98-8.4$ & $0.000^{\text {*** }}$ \\
\hline & Buffalo & Reference & - & - & - & - & - \\
\hline \multirow[t]{4}{*}{ Age } & & & & & & & $0.001^{\text {*** }}$ \\
\hline & $\begin{array}{l}<1 \text { year } \\
1 \text { year }\end{array}$ & Reference & - & - & - & - & - \\
\hline & $1-2$ years & 0.854 & 0.235 & 13.26 & 2.35 & $1.48-3.7$ & $0.000^{* * *}$ \\
\hline & $>2$ years & 0.286 & 0.21 & 1.84 & 1.33 & $0.88-2.01$ & $0.18^{\mathrm{NS}}$ \\
\hline $\begin{array}{l}=\text { Beta } \\
I=\text { con }\end{array}$ & coefficie & nt, $\quad \mathrm{SE}=$ & stand & & error, & $\begin{array}{l}\mathrm{OR}=\text { odd } \\
\text { difference }\end{array}$ & \\
\hline
\end{tabular}

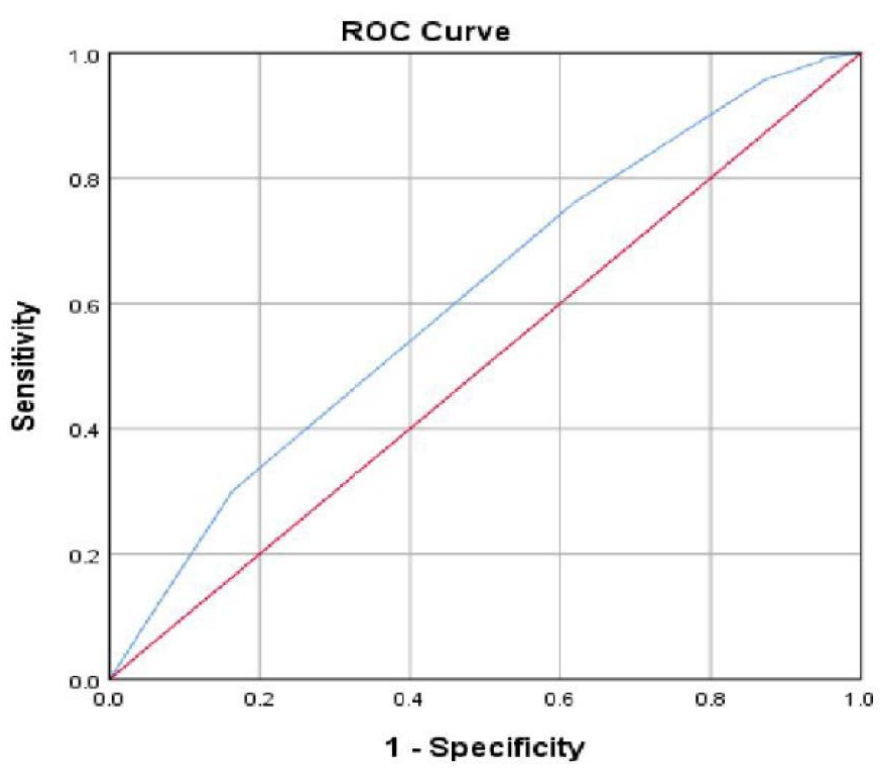

Figure 1: Showing the ROC curve (A measure of goodness-offit of the final multivariate logistic regression model). $\mathrm{AUC}=0.62$ at $95 \% \mathrm{CI}(0.57-0.65), \mathrm{SE}=0.02$, p-value $=0.000$.

\section{CONCLUSION}

Lumpy skin disease became endemic in Egypt and causes sporadic attacks over the year, mainly in adult animals during the summer season. Also, Cattle still have more likelihood to be infected with the LSD virus. In this context, early detection of LSD seropositivity among cattle of age $1-2$ years and the application of control measures among localities are the methods of choice to minimize future LSD outbreaks in Egypt.

\section{CONFLICT OF INTEREST}

There is no conflict of interest.

\section{AUTHORS' CONTRIBUTION}

All authors contributed equally.

\section{REFERENCES}

-Abd Elmohsen M, Selim A, Abd Elmoneim AE (2019). Prevalence and molecular characterization of Lumpy Skin Disease in cattle. Benha Vet. Med.J.37(1): 144-147. https:// doi.org/10.21608/bvmj.2019.18293.1118

- Abdallah FM, El Damaty HM, Kotb GF (2018). Sporadic cases of lumpy skin disease among cattle in Sharkia province, Egypt: Genetic characterization of lumpy skin disease virus isolates and pathological findings. Vet. World. 11(8): 1150. https://doi.org/10.14202/vetworld.2018.1150-1158

-Abera Z, Degefu H, Gari G, Kidane M (2015). Sero-prevalence of lumpy skin disease in selected districts of West Wollega zone, Ethiopia. BMC Vet. Res. 11(1): 1-9. https://doi. org/10.1186/s12917-015-0432-7

-Ahmed AM, Dessouki AA (2013). Abattoir-based survey and histopathological findings of lumpy skin disease in cattle at Ismailia abattoir. Int. J. Biosci. Biochem. Bioinform. 3(4): 372.

-Allam AM, Elbayoumy MK, Abdel-Rahman EH, Hegazi AG, Farag TK (2020). Molecular characterization of the 2018 outbreak of lumpy skin disease in cattle in Upper Egypt. Vet. World. 13(7): 1262. https://doi.org/10.14202/ vetworld.2020.1262-1268

-Al-Salihi KA (2014). Lumpy skin disease: Review of literature. Mirror Res. Vet. Sci. Anim. 3(3): 6-23.

-Al-Salihi, KA, Hassan IQ (2015). Lumpy skin disease in Iraq: study of the disease emergence. Transboundary and emerging diseases. 62(5): 457-462. https://doi.org/10.1111/ tbed.12386

-Ayelet G, Haftu R, Jemberie S, Belay A, Gelaye E, Sibhat B, Asmare K (2014). Lumpy skin disease in cattle in central Ethiopia: outbreak investigation and isolation and molecular detection of the virus. Revue Scientifique et technique. 33(3): 877-87. https://doi.org/10.20506/rst.33.3.2325

-Bhanuprakash V, Indrani BK, Hosamani M, Singh RK (2006). The current status of sheep pox disease. Comp. Immunol. Microbiol. Infect. Dis. 29(1): 27-60. https://doi. org/10.1016/j.cimid.2005.12.001

-Dohoo I, Martin W, Stryhn H (2003). Veterinary epidemiologic research: AVC Inc. Charlottetown, Prince Edward Island, Canada. 1: $341-343$.

-Elhaig MM, Selim A, Mahmoud M (2017). Lumpy skin disease in cattle: Frequency of occurrence in a dairy farm and a preliminary assessment of its possible impact on Egyptian buffaloes. Onderstepoort J. Vet. Res. 84(1), 1-6. https://doi. org/10.4102/ojvr.v84i1.1393

- Gari G, Abie G, Gizaw D, Wubete A, Kidane M, Asgedom H, Tuppurainen ES (2015). Evaluation of the safety, immunogenicity, and efficacy of three capripoxvirus vaccine strains against lumpy skin disease virus. Vaccine. 33(28): 3256-3261. https://doi.org/10.1016/j.vaccine.2015.01.035

-Hodhod A, Elgendy E, Abd El-Moniem MI, Ibrahim MS 
(2020). Isolation and Molecular Characterization of Lumpy Skin Disease Virus in Egypt During 2017-2018. Skin. Eur. J. Pharma. Med. Res. 7(1): 96-103.

-Ince OB, Türk T (2019). Analyzing risk factors for lumpy skin disease by a geographic information system (GIS) in Turkey. J. Hellenic Vet. Med. Soc. 70(4): 1797-1804. https://doi. org/10.12681/jhvms.22222

-Kendall PE, Webster JR (2009). Season and physiological status affects the circadian body temperature rhythm of dairy cows. Livestock Sci. 125(2-3): 155-160. https://doi. org/10.1016/j.livsci.2009.04.004

- Kiplagat SK, Kitala PM, Onono JO, Beard PM, Lyons NA (2020). Risk factors for outbreaks of lumpy skin disease and the economic impact in cattle farms of Nakuru County, Kenya. Front. Vet. Sci. 7: 259. https://doi.org/10.3389/ fvets.2020.00259

- Molla W, Frankena K, Gari G, Kidane M, Shegu D, de Jong MC (2018). Seroprevalence and risk factors of lumpy skin disease in Ethiopia. Prev. Vet. Med. 160: 99-104. https://doi.

org/10.1016/j.prevetmed.2018.09.029

- Ochwo S, VanderWaal K, Munsey A, Nkamwesiga J, Ndekezi C, Auma E, Mwiine FN (2019). Seroprevalence and risk factors for lumpy skin disease virus seropositivity in cattle in Uganda. BMC Vet. Res. 15(1): 1-9. https://doi.org/10.1186/ s12917-019-1983-9

-Salib FA, Osman AH (2011). Incidence of lumpy skin disease among Egyptian cattle in Giza Governorate, Egypt. Vet. World. 4(4):162-167. https://doi.org/10.5455/ vetworld.2011.162-167

-Tuppurainen ESM, Oura CAL (2012). Lumpy skin disease: an emerging threat to Europe, the Middle East and Asia. Transboundary Emerg. Dis. 59(1): 40-48. https://doi. org/10.1111/j.1865-1682.2011.01242.x

-Weiss KE (1968). Lumpy skin disease virus. In Cytomegaloviruses. Rinderpest Virus. Lumpy Skin Disease Virus. Springer, Berlin, Heidelberg. (pp. 111-131). https:// doi.org/10.1007/978-3-662-39771-8_3 